\title{
MENINGKATKAN KEMAMPUAN PEMAHAMAN KONSEP MATEMATIS MELALUI PEMBELAJARAN PROJECT BASED LEARNING MENGGUNAKAN BAHAN AJAR GAMIFIKASI
}

\author{
Anggara Yugo Pratama', ${ }^{1}$ Farida $^{2}$, Rizki Wahyu Yunian Putra ${ }^{3}$ \\ Universitas Islam Negeri Raden Intan Lampung ${ }^{1,2,3}$ \\ anggarayugopratama2@gmail.com,farida@radenintan.ac.id, \\ rizkiwahyuyp@radenintan.ac.id
}

\begin{abstract}
The background of this research is due to the low understanding of mathematical concepts, in this case, a research is conducted which aims to obtain results from the application of project-based learning models to improve the ability to understand concepts. The subjects of this study were students of class VIII MTS Al-Hikmah Bandar Lampung using a sample of two classes and one control class. One away ANOVA test is an analysis used in research with a sig of 0.05 . Based on the research results, it can be concluded that the understanding of the first concept of students in the experimental class one is better than the experimental class two and the control class. The project based learning model using gamification teaching materials in the experimental class 1 has a high enough increase. While the second experimental class is not better than the first experimental class in increasing understanding of the concept because it only applies the learning model without the presence of media. In the control class, students tend to be more lethargic in participating in learning activities due to boredom with non-innovative learning methods and the absence of supporting media in the learning process.
\end{abstract}

Key Words: Understanding of Mathematical Concepts, Project Based Learning, Gamifikasi

\begin{abstract}
Abstrak: Latar belakang dari penitian ini dikarenakan masih rendahnya pemahaman konsep matematis,dalam hal ini maka diadakanya penelitian yang bertujuan untuk memeperoleh hasil dari penerapan model pembelajaran project based learning untuk meningkatkankemampuan pemahaman konsep. Subjek penelitian ini adalah peserta didik kelas VIII MTS Al-Hikmah Bandar Lampung dengan menggunakan sampel dua kelas dan satu kelas kontrol. Uji one away anova merupakan analasis yang dipakai dalam penelitian dengan sig 0,05. Berdasarkan hasil penelitian dapat disimpulakan pemahaman konsep perta didik di kelas eksperimen satu lebih baik dibandingkan dengan kelas eksperimen dua dan kontrol. model pembelajaran project based learning dengan menggunakan bahan ajar gamifikasi pada kelas eksperimen satu terjadi peningkatan yang cukup tinggi. Sedangkan kelas eksperimen dua tidak lebih baik dari kelas eksperimen satu dalam peningkatan pemahamn konsep dinkarenakan hanya menerapkan model pembelajaranya saja tanpa adanya media. Pada kelas kontrol peserta didik cenderung lebih lesu dalam mengikuti kegiatan pembelajaran dikarenakan adanya rasa bosan dengan cara belajar yang tidak inovatif dan tidak adanya media yang menunjang dalam kegiatan proses pembelajaran.
\end{abstract}

Kata Kunci: Pemahaman Konsep Matematis, Project Based Learning, Gamifikasi 


\section{PENDAHULUAN}

Pembelajaran matematika adalah suatu hal yang tidak bisa dipisahkan dari kehidupan maka dari itu jam belajar matematika lebih banyak dibandingkan dengan yang lainnya, dikarenakan matematika sangat erat hubungannya dengan perkembangan. Di era modern ini matematika menjadi sangat penting guna menunjang kemajuan teknologi. Hal terpenting dalam ilmu matematika yaitu memahami sebuah konsep, pemahaman konsep adalah salah satu faktor yang penting dalam pembelajaran di kelas dikarenakan peserta didik akan lebih mudah menyerap pelajara jika memahami konsep terlebih dahulu (Nugroho, 2017). Depdiknas dalam Jihat dan Haris, kemahiran yang harus dimiliki dalam belajar merupakan salah satu kemahiran yang ada di pemahaman konsep, erat kaitannya anatara konsep dan penggunaanya dengan tepat untuk memecahakan suatu permasalahan (pratiwi, 2016). Pemahaman konsep menjadi salah satu factor penting guna menentukan hasil belajar peserta didik, apabila peserta didik memiliki pemahaman konsep yang baik maka akan sejalan dengan hasil belajar yang baik pula (rina dkk., 2015)Untuk melatih pemahaman konsep peserta didik ada beberapa cara salah satunya dengan memilih model pembelajaran yang tepat, hal ini dimaksudkan guna membantu peserta didik dalam memahami materi untuk dijadikan sebagai sebuah konsep dan dapat berpengaruh terhadap peningkatan pemahamn konsep (anggoro, 2015). Salah satunya dengan menggunakan model pembelajaran project based learning. Pemilihan model akan lebih efektif jika dikombinasikan dengan bahan ajar ataupun media pembelajaran guna menarik minat belajar peserta didik, salah satunya dengan menggunakan bahan ajar gamifikasi. Bahan ajar gamifikasi dapat menarik minat belajar peserta didik dikarenakan bahan ajar gamifikasi berbentuk game ataupun permainan. (Utami, 2015). Dari uraian permasalah di atas peneliti mengharapkan dampak positif dari model pembelajaran project based learning berbantuan gamifikasi terhadap peningkatan kemampuan pemahaman konsep matematis. Keterbaruan dalam penelitian terletak pada bahan ajar gamifikasi.

\section{TINJAUAN TEORETIS}

Project-based learning sering disebut kegiatan belajar mengandung unsur proyek (Kosasih, 2014). Projectbased learning adalah suatu pemecahan masalah terjadi di proses belajar yang memfokuskan pada peserta didik dengan menghasilkan karya peserta didik dan realistik (Badar, 2014)

Langkah-langkah model pembelajaran PjBL (Yunianta, 2015):

\section{Penentuan pernyataan mendasar (start with the essential question)}

Kegiatan proses belajar akan diawali penyataan yang essential yaitu pernyataan fungsinya dalam pelaknasaan tugas yang diberikan ke peserta didik untuk menjalankan suatu kegiatan dengan relevan.

2. Mendesain perencanaan proyek (design a plan or the project)

Isi dari perencanaanya yaitu arahan permainan untuk memilih aktivitas yang membantu untuk menjawab pernyataan, memilah dari subyek yang ada dan menglarifikasi alat 
yang dapat memudahkan dalam menyelesaiakan suatu proyek.

3. Menyusun Jadwal (creat a schedule)

Pendidik dan peserta didik berdiskusi menata pelaksanaan kegiatan untuk mengerjakan proyek agar terjadi rasa "memiliki" proyek tersebut. Adapun aktifitas untuk langkah-langkahnya adalah:
a. Menentukan rencana awal penyelesaian proyek,

b. Menentukan batas akhir penyelesain proyek,

c. Menstimulus peserta didik untuk merencanakan cara baru.

$\begin{array}{llr}\text { d. Memberi arahan } & \text { kepada } \\ \text { peserta } & \text { didik } & \text { disaat }\end{array}$ pelaksaanya dalam membuat hal yang tidak ada kaitanya dengan proyek.

e. Peserta didik diharapakan membuat suata narasi yang berisi tentang penjelasan dan alas an mengenai pemilihan cara.

4. Mengawasi peserta didik dan kemajuan proyek (monitor the student and the progrees of the project)

Pemantauan diterapkan pendidik dengan memberi fasilitasi peserta didik di dalam kegiatan dan dapatberfungsi sebagai pembimbing di setiap kegiatan peserta didik. Rubik yang merekam kegiatan peserta didik tujuaan untuk mematau perkembangan peserta didik.

5. Menguji Hasil (assess the outcome)
Mengevaluasi bertujuan untuk mengetahui kadar pencapaian masing-masing peserta didik, memberi tanggapan tingkat pemahaman peserta didik, dan membantu pendidik untun mengumpulkan langkah-langkah yang baik dipakai dalam kegiatan selanjutnya.

6. Mengevaluasi pengalaman (evaluate the experience)

Hasil akhir dari kegiatan belajar dengan hasil proyek yang dilakukan pada akhir pembelajaran kemudian peserta didik diharusakan menyampaikan pengaalaman dalam menjalankan proyek. Pendidik dan peserta didik berdiskusi bertujan untuk mendapatkan suatu perbaikan dan hal baru untuk memperbaiki kegiatan selam pembelajaran (Yunianta, 2015). Untuk menarik minat peserta didik diberikan bahan ajar atau media yang membuat peserta didik atusias dalam mengikuti proses pembelajaran di kelas salah satu dengan menggunakan gamifikasi.

Gamifikasi adalah Suatu kegiatan yang dirancang dengan memasukan unsur-unsur game. Rancangan ini bertujuan mebuat suasana yang lebih menarik sehingga materi yang disampaikan mudah dipahami dan peserta didik termotivasi untuk menjadi yang terbaik. Gamifikasi di dalam tampilann materinya lebih di dominasi dengan gambar, yang mengandung unsur perbincangan dan pertanyaan gambar tersebut yang harus dikerjakan sebagai bahan pembelajaran 
(khoirunisa dkk., 2018). Heni Jusuf sudah melakukan penelitian yang dalam Proses Pembelajaran" dengan hasilnya yaitu gamifikasi dapat membuat pelajaran lebih aktif, dan juga tidak membosankan. Sedangkan Arif Prambayun dan Mohamad Farozi dalam penelitiannya yang berjudul "Pola Perancangan Gamifikasi untuk Membangun Engagement Peserta didik dalam Belajar" memberikan hasil dan respon yang positif dari peserta didik. berjudul "Penggunaan Gamifikasi

\section{METODOLOGI PENELITIAN}

Metode penelitian merupakan cara yang di aplikasikan di dalam penelitian(Ningsih, 2014). Di dalam penelitian ini terkandung dua variabel yaitu variabel bebas dan satu variable terikat, penelitian yang mengambil subjek yang diteliti pada manusia yang merupakan penelitian eksperimen, eksperimen yang dipakai peneliti ialah penelitian eksperimen semu maupun kuasi eksperimen. Penelitian yang akan di angkat peneliti ialah responden di bagi menjadi tiga bagian yaitu :

Tabel 1

Desain Penelitian

\begin{tabular}{cccc}
\hline Kelompok & Pre-test & Treatment & Post-Test \\
\hline Eksperimen 1 & $\mathrm{Y}_{1}$ & $\mathrm{X}_{1}$ & $\mathrm{Y}_{2}$ \\
\hline Eksperimen 2 & $\mathrm{Y}_{3}$ & $\mathrm{X}_{2}$ & $\mathrm{Y}_{4}$ \\
\hline Kontrol & $\mathrm{Y}_{5}$ & $\mathrm{X}_{3}$ & $\mathrm{Y}_{6}$ \\
\hline Keterangan: & & Populasi penelitian & yaitu seluruh
\end{tabular}

$\mathrm{Y}_{1}=$ pre-test diberikan kepada kelas eksperimen 1.

$\mathrm{Y}_{2}=$ post-test diberikan kepada kelas eksperimen 1.

$\mathrm{Y}_{3}=$ pre-test diberikan kepada kelas eksperimen 2.

$\mathrm{Y}_{4}=$ post-test diberikan kepada kelas eksperimen 2.

$\mathrm{Y}_{5}=$ pre-test diberikan kepada kelas kontrol

$\mathrm{Y}_{6}=$ post-testdiberikan kepada kelas kontrol

$\mathrm{X}_{1}=$ pembelajaran matematika menggunkan model Project Based Learning ( $P j B L)$ bahan ajar gamifikasi $\mathrm{X}_{2}=$ pembelajaran matematika menggunkan model Project Based Learning ( $P j B L)$

$\mathrm{X}_{3}=$ pembelajaran matematika pada kelas kontrol dengan metode konvensional
Populasi penelitian yaitu seluruh peserta didik kelas 8 MTs Al-Hikmah Bandar lampung tahun pelajaran 2020/2021. Dalam poenelitian ini mengambil acak sampel dari suatu populasi tanapa memandang tingkatan wawamcara dan dokumentasi merupakan teknik pengumpulan data yang di pakai di penelitian ini. Penelitian ini menggunakan teknik analisis data berupa uji normalitas, uji homogenitas dipakai untuk sample yang homogen,uji hipotesis yang di pakai yaitu one away meruapakan suatu teknik analisis data yang berguna untiuk mengetahui perbedaan nialai, uji komparasi ganda menggunakan metode scheffe, uji $\mathrm{N}$-gain ddipakai untuk memperoleh peningkatan kemampuan peserta didik dengan menggunakan post-test dan pre-test (sudjana, 2005). dalam populasi tersebut.tes, 


\section{HASIL DAN PEMBAHASAN}

Penilitia ini dilakukan di $\mathrm{mts}$ alhikmah Bandar lampung mengambil sampel tiga kelas yaitu VIII A kelas eksperimen 1 dan memberikan treatmen model pembelajaran project based learning, kelas VIII B eksperimen 2 dan di berikan treatmen model pembelajaran project based learning menggunakan bahan ajar gamifikasi dan kelas VIII C sebagai kelas control dengan menggunakan pembelajaran konvensional. Sebelum diberi treatment perlunya di lakukan pre-test untuk memngetahui pemahaman konsep siswa pada materi SPLDV dengan hasil berikut :

\section{Tabel 2}

Deskripsi Data Hasil Pretest Pemahaman Konsep Matematis

\begin{tabular}{ccccccccc}
\hline \multirow{2}{*}{ Kelompok } & $X_{\max }$ & $X_{\min }$ & \multicolumn{2}{c}{ Ukuran Terdentasi Sentral } & \multicolumn{2}{c}{$\begin{array}{c}\text { Ukuran Variansi } \\
\text { Kelompok }\end{array}$} \\
\cline { 3 - 9 } & & & $\bar{x}$ & $M_{o}$ & $M_{e}$ & $\mathrm{R}$ & $\mathrm{S}$ \\
\hline Eksperimen 1 & 75 & 30 & 51,67 & 50 & 50 & 45 & 10,75 \\
\hline Eksperimen 2 & 75 & 30 & 49,67 & 50 & 50 & 45 & 11,66 \\
\hline Kontrol & 70 & 30 & 48,33 & 50 & 50 & 45 & 12,68 \\
\hline & & \multicolumn{4}{c}{ maksimumnya yaitu } & 70 & dan nilai
\end{tabular}

Berdasarkan Tabel 2 hasil nilai tes awal (pretest) pada kelas eksperimen 1 memliki nilai tertinggi 75 dan nilai terendahnya yaitu 30, memiliki nilai rata-rata sebesar 51,67, memiliki nilai modus dan median sebesar 50. Pada kelas eksperimen 2 memiliki nilai eksperimen nilai tertinggi sebesar 75 dan memiliki nialai minimum 30, memiliki nilai rata-rata sebesar 49,67, modus dan median pada kelas eksperimen 2 yaitu sebesar 50. Pada kelas kontrol memiliki nilai terendahnya 30 , rata-rata nilai peserta didik pada kelas kontrol 48,33 dan kelas kontrol memiliki nilai modus median yang sama yaitu 50 .

Selanjutnya setelah dilakuakan pretest maka diterapkan treatment pada setiap kelas. Jika sudah diaplikasikannya treatment berlanjut perlu diadakannya tes yang terakhir atau posttest untuk mengetahui seberapa besar pengaruh pemahaman konsep matematis dan hasil sebagai berikut ini :

Tabel 3

Deskripsi Data Hasil Postest Pemahaman Konsep Matematis

\begin{tabular}{cccccccc}
\hline \multirow{2}{*}{ Kelompok } & \multirow{2}{*}{$X_{\max }$} & $X_{\min }$ & \multicolumn{2}{c}{ Ukuran Terdentasi Sentral } & \multicolumn{2}{c}{$\begin{array}{c}\text { Ukuran Variansi } \\
\text { Kelompok }\end{array}$} \\
\cline { 3 - 8 } & & & $\bar{x}$ & $M_{o}$ & $M_{e}$ & $\mathrm{R}$ & $\mathrm{S}$ \\
\hline Eksperimen 1 & 100 & 70 & 84 & 84 & 82,5 & 30 & 8,65 \\
\hline Eksperimen 2 & 100 & 55 & 74,16 & 78 & 75 & 66 & 12,04 \\
\hline Kontrol & 100 & 50 & 68,5 & 77 & 68,5 & 45 & 12,60
\end{tabular}

Berdasarkan Tabel 3 hasil nilai postest peserta didik pada kela eksperimen 1 memiliki nilai maksimum sebesar 100 dan memiliki nilai minimum sebesar 70, dengan nilai rata-ratanya sebesar 84, nilai modus nya pada kelas eksperimen 1 yaitu 84 dan nilai mediannya sebesar 82,5. Pada kelas eksperimen 2 memiliki nilai maksimumnya sebesar 100 dan memiliki nilai minimum nya sebesar 55, dengan nilai rata-ratanya sebesar 
74,16, nilai modus pada kelas nilai modus pada kelas kontrol yaitu eksperimen 2 yaitu sebesar 78 dan sebesar 77 dan memiliki nilai median memiliki nilai mediannya sebesar 75. sebesar 68,5. Untuk mengetahui Pada kelas terakhir yaitu kelas kontrol sebesar mana peningkatan melalui uji memeiliki nilai maksimum sebesar $100 \mathrm{~N}$-gain melalui data pretest dan posttest dan nilai minimumnya sebesar 50, yang telah di dapat hasilanya tersaji dengan nialai rata-ratanya sebesar 68,5, sebagai berikut :

Tabel 4.

Deskripsi Data Hasil N-Gain Pemahaman Konsep Matemati

\begin{tabular}{cccccccc}
\hline \multirow{2}{*}{ Kelompok } & $X_{\max }$ & $X_{\min }$ & \multicolumn{2}{c}{ Ukuran Terdentasi Sentral } & \multicolumn{2}{c}{$\begin{array}{c}\text { Ukuran Variansi } \\
\text { Kelompok }\end{array}$} \\
\cline { 4 - 8 } & & & $\bar{x}$ & $M_{0}$ & $M_{e}$ & $\mathrm{R}$ & $\mathrm{S}$ \\
\hline $\begin{array}{c}\text { Eksperimen } \\
1\end{array}$ & 1,000 & 0,538 & 0,695 & 0,600 & 0,652 & 0,462 & 0,036 \\
\hline $\begin{array}{c}\text { Eksperimen } \\
2\end{array}$ & 1,000 & 0,357 & 0,520 & 0,500 & 0,477 & 0,643 & 0,037 \\
\hline Kontrol & 1,000 & 0,250 & 0,404 & 0,444 & 0,367 & 0,750 & 0,035 \\
\hline
\end{tabular}

Berdasarkan Tabel 4 hasil nilai n-gain peserta didik dengan nilai tertinggi pada kelas eksperimen 1 sebesar 1,000 kelas eksperimen 2 sebesar 1,000, dan kelas kontrol sebesar 1,000. Nilai terendah peserta didik pada kelas eksperimen 1 sebesar 0,538 , kelas eksperimen 2 sebesar 0,357, dan kelas kontrol sebesar 0,250. Rata-rata nilai peserta didik pada kelas eksperimen 1 diperoleh nilai 0,695 , kelas eksperimen 2 dengan nilai 0,520, dan kelas kontrol dengan nilai 0,404 . Modus pada kelas eksperimen 1 yaitu 0,600 , kelas eksperimen 2 yaitu 0,500 , dan kelas kontrol yaitu 0,444 . Nilai tengan atau (median) pada kelas eksperimen 1 sebesar 0,652, kelas eksperimen 2 sebesar 0,477, dan kelas kontrol sebesar 0,367

Tabel 5

Hasil Uji Komparasi Ganda N- Gain

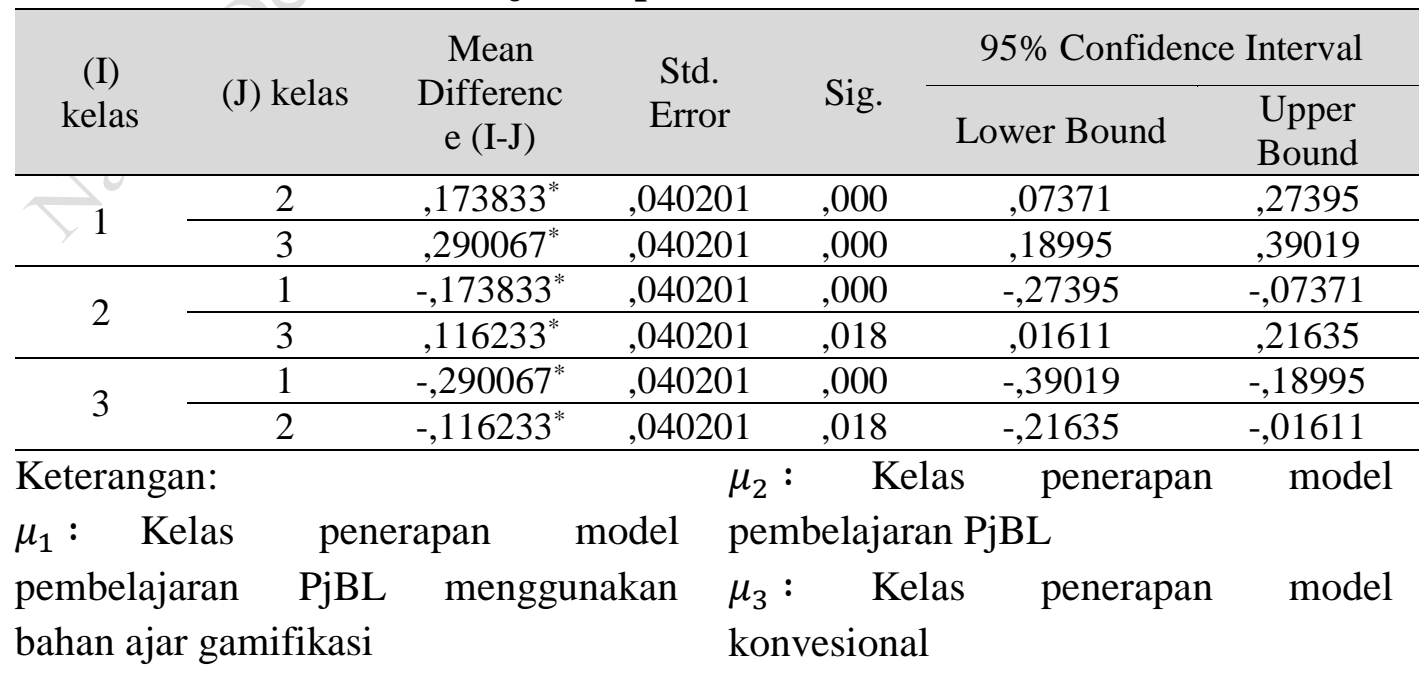


Berdasarkan hasil perhitungan pada Tabel 4.21 diperoleh hasil terhadap masing-masing model pembelajaran, dengan taraf signifikan 0,05 yaitu sebagai berikut:

1) Pada $H_{0}: \mu_{1} \neq \mu_{2}$ dengan perolehan nilai $\operatorname{sig}=0,000$ yang berarti sig. $<\alpha \quad$ sehingga disimpulkan bahwa $H_{0}$ ditolak, artinya terdapat perbedaan yang signifikan antara peserta didik dengan model pembelajaran $\mathrm{PjBL}$ menggunakan bahan ajar gamifikasi dan model pembelajaran PjBL terhadap kemampuan pemahman konsep matemtis.

2) Pada $H_{0}: \mu_{1}=\mu_{3}$ dengan perolehan nilai $\operatorname{sig}=0,018$ yang berarti sig. $>\alpha$ sehingga disimpulkan bahwa $H_{0}$ diterima, artinya tidak ada perbedaan yang signifikan antara peserta didik dengan model pembelajaran $\mathrm{PjBL}$ menggunakan bahan ajar gamifikasi dan model pembelajaran konvesional terhadap kemampuan pemahman konsep matemtis.

3) Pada $\mathrm{H}_{0}: \mu_{2}=\mu_{3}$ dengan perolehan nilai $\operatorname{sig}=0,018$ yang berarti sig. $>\alpha \quad$ sehingga disimpulkan bahwa $H_{0}$ diterima, artinya tidak ada perbedaan yang signifikan antara peserta didik dengan model pembelajaran PjBL dan model pembelajaran konvesional terhadap kemampuan pemahman konsep matemtis.

\section{SIMPULAN DAN SARAN}

Berdasarkan hasil yang telah diperoleh dari analisis data dan pengujian hipotesis dapat disimpulkan "terdapat perbedaan peningkatan kemampuan pemahaman konsep matematis ssiswa dengan model pembelajaran PjBL menggunakan bahan ajar gamifikasi, model pembelajaran PjBL, dan model pembelajaran konvesional"

Berdasarkan hasil penilitian yang di dapat, penulis meyaranakan penggunaan model pembelajaran project based learning dengan menggunakan bahan ajar gamifikasi merupakan salah satu cara membuat pemahaman kosep matematis peserta didik menjadi lebih baik,kemudian untuk peserta didik diharapkan dapat lebih aktif, kreatif dalam menhgikuti pembelajaran dan pendidik diharap lebih inovatif dalam segi media pembelajaran dan model pembelajaran.

\section{DAFTAR PUSTAKA}

Anggoro, Suharji. (2015). Peningkatan Pemahaman Konsep Belajar Matematika Melalui Metode Project-Based Learning (PTK Di Kelas VII C SMP Negeri 4 Wonogiri).

Badar, A.-T. (2014). Mendesain Model Pembelajaran Inovatif, Progresif, Dan Kontekstual. Prenadamedia Group.

Khoirunisa, Yoraida, Farida, \& Putra, R. W. Y. (2018). "Pengembangan Bahan Ajar Gamifikasi Pada Materi Bangun Ruang Sisi Lengkung." Jurnal Penelitian Dan Pembelajaran Matematika, 11, 2.

Kosasih, E. (2014). Strategi Belajar Dan Pelajaran. Yrama Idya. 
Ningsih, E. M. (2014). Metode Penelitian Terapan Bidang Pendidikan. Alfabeta.

Nugroho, Aji Arif, \& Dkk. (2017). . "Pengembangan Blog Sebagai Media Pembelajaran Matematika." Al-Jabar: Jurnal Pendidikan Matematik, 8, 2.

Pratiwi, D. D. (2016). Pembelajaran Learning Cycle 5E Berbantuan Geogebra Terhadap Kemampuan Pemahan Konsep Matematis. AlJabar : Jurnal Pendidikan Matematika, 7(2), 9.

Rina, Rozalina, Mukhni, Muhkni, \& Puspa. (2015). "Pengaruh Penerapan Model Pembelajaran Project Based Learning Terhadap Pemahaman Konsep Matematis Siswa Kelas XI IPA MAN 3 Padang Tahun Pelajaran 2014/2015.
Sudjana. (2005). Metode Statistika. Tarsito.

Utami, D. D. (2015). Kahoot \& Assure, Sebuah Kombinasi Gamefikasi \& Model Pembelajaran Untuk Membangun Partisipasi Aktif, Motifasi Dan Pengalaman Belajar Siswa. Prosiding Simposium Nasional Inovasi Dan Pembelajaran Sains.

Yunianta, H. (2015). Kemampuan Berpikir Kreatif Siswa Pada Implemen Project Based Learning Dan Peer And SelfAssesment. Unnes Journal Or Mathematics Education Research, Vol.1 No 12. 